\title{
Resistance of diethylenetriaminepentaacetic acid to anaerobic biodegradation
}

\author{
Evelyn Alarcón \\ Environmental Science Center EULA-Chile \\ Universidad de Concepción \\ P.O. Box 160-C \\ Concepción, Chile \\ Jacqueline Decap \\ Environmental Science Center EULA-Chile \\ Universidad de Concepción \\ P.O. Box 160-C \\ Concepción, Chile \\ Gladys Vidal* \\ Environmental Science Center EULA-Chile \\ Universidad de Concepción \\ P.O. Box 160-C \\ Concepción, Chile \\ Fax: 5641204067 \\ E-mail: glvidal@udec.cl
}

Financial support: FONDECYT Grants 1010644 and 1040987.

Keywords: anaerobic biodegradation, DTPA, kraft mill effluent.

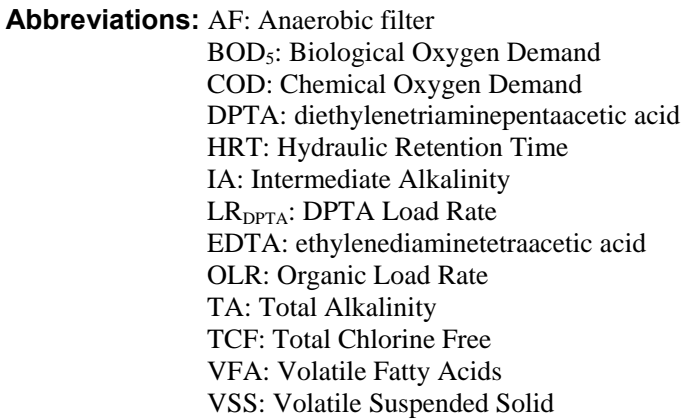

Abbreviations: AF: Anaerobic filter

BOD $_{5}$ : Biological Oxygen Demand

COD: Chemical Oxygen Demand

DPTA: diethylenetriaminepentaacetic acid

HRT: Hydraulic Retention Time

IA: Intermediate Alkalinity

LR $_{\text {DPTA: }}$ DPTA Load Rate

EDTA: ethylenediaminetetraacetic acid

OLR: Organic Load Rate

TA: Total Alkalinity

TCF: Total Chlorine Free

VFA: Volatile Fatty Acids

VSS: Volatile Suspended Solid

Kraft mills are responsible for the massive discharge of highly polluted effluents, and new bleaching processes (i.e. Total Chlorine Free (TCF)) is presented as a feasible option to reduce this environmental impact. However, increased TCF pulp production is accompanied by an increase in chelate use. The most commonly used chelates, ethylenediaminetetraacetic acid (EDTA) and diethylenetriaminepentaacetic acid (DPTA), are considered to be relatively persistent substances in water treatment plants, and consequently environmentally critical compounds. The purpose of this work is to investigate DPTA behaviour in an anaerobic system. An Anaerobic Filter (AF) was operated with three different DPTA load rates $\left(\mathbf{L R}_{\mathrm{DPTA}}\right.$ $=0.07-0.28 \mathrm{gDPTA} / \mathrm{L} \times \mathrm{d}$ ), and the operating strategy was to maintain the anaerobic system stable during the entire operation (alkalinity ratio below 0.3 ). The AF's maximum Chemical Oxygen Demand (COD) removal was $59 \%$, whereas the Biological Oxygen Demand $\left(\mathrm{BOD}_{5}\right)$ was around $95 \%$. However, only $5 \%$ of DPTA removal was observed under anaerobic conditions during the first operating period. Scanning electronic microscopy indicates that the operating system reduced microorganism biodiversity.

In recent years, important technological innovations have been implemented in the kraft mills worldwide, aimed at reducing both water consumption and toxic contaminant generation. Thus, water circuit closures as well as new pulping and bleaching processes have been introduced. Some of those innovations, such as extended cooking,

* Corresponding author 
oxygen predelignification and TCF bleaching, have been implemented in Chilean mills, improving their environmental performance (Videla and Diez, 1997).

The TCF bleaching process employs hydrogen peroxide $\left(\mathrm{H}_{2} \mathrm{O}_{2}\right)$ instead of chlorine compounds to remove residual lignin. However, the heavy metals contained in wood (Kaluza et al. 1998) and water catalyze the production of $\mathrm{OH}^{-}$radicals, which then readily react with pulp carbohydrates, resulting in yield losses and a decrease in pulp strength (Rodriguez et al. 1999; Van Ginkel et al. 1999).

Chelating agents are used in pulp and paper processing to control the action of different metal ions. Although TCF pulp production eliminates the use of chlorine, EDTA and DPTA concentrations will increase in TCF pulp production wastewaters. EDTA and DTPA concentrations in pulp mill effluent treatment outfalls have found between 10 and 60 $\mathrm{mg} / \mathrm{L}$ (Suss and Nimmerfroh, 1993). Chelating agents are often considered as a compound that cannot be biologically treated (Alder et al. 1990; Saunamäki, 1995); nevertheless, recent studies have shown that EDTA has been degraded at slightly alkaline $\mathrm{pH}$ values with activated sludge treatment (Van Ginkel et al. 1997; Van Ginkel et al. 1999).

Hinck et al. (1997) studied the DPTA transformation in conventional effluent treatment processes. The batch assays were inoculated with four different biomass under aerobic conditions. To apply selection pressure to bacterial populations, the only carbon source was DPTA (Hinck et al. 1997). The results indicated that DPTA is not biodegradable under aerobic conditions. Additionally, Larisch and Duff (2000) studied the effect of different DPTA concentrations (from 50 to $875 \mathrm{mg} / \mathrm{L}$ ) in an activated sludge reactor, showing that after exposure to elevated DPTA levels (> $500 \mathrm{mg}$ DPTA/L), floc density was considerably reduced and $\mathrm{BOD}_{5}$ removal efficiency was reduced by up to 39\%. Virtapohja and Alen (1999) found similar results in large-scale activated sludge plants, observing reductions of 33 and 54\% of DPTA and EDTA, respectively. Considering that all of the studies mentioned were performed under aerobic conditions and no studies have been performed under anaerobic conditions, the objective of this study was to evaluate the biodegradation of the Fe-DPTA complex contained in TCF synthetic effluent in an anaerobic filter reactor.

Table 1. TCF synthetic influent characteristics.

\begin{tabular}{|l|c|}
\hline \multicolumn{1}{|c|}{ Parameter } & Range \\
\hline $\mathrm{pH}$ & $6.5-7.2$ \\
\hline $\mathrm{COD}(\mathrm{g} / \mathrm{L})$ & $0.267-0.296$ \\
\hline $\mathrm{BOD}_{5}(\mathrm{~g} / \mathrm{L})$ & $0.087-0.120$ \\
\hline $\mathrm{DTPA}(\mathrm{g} / \mathrm{L})$ & $0.088-0.113$ \\
\hline
\end{tabular}

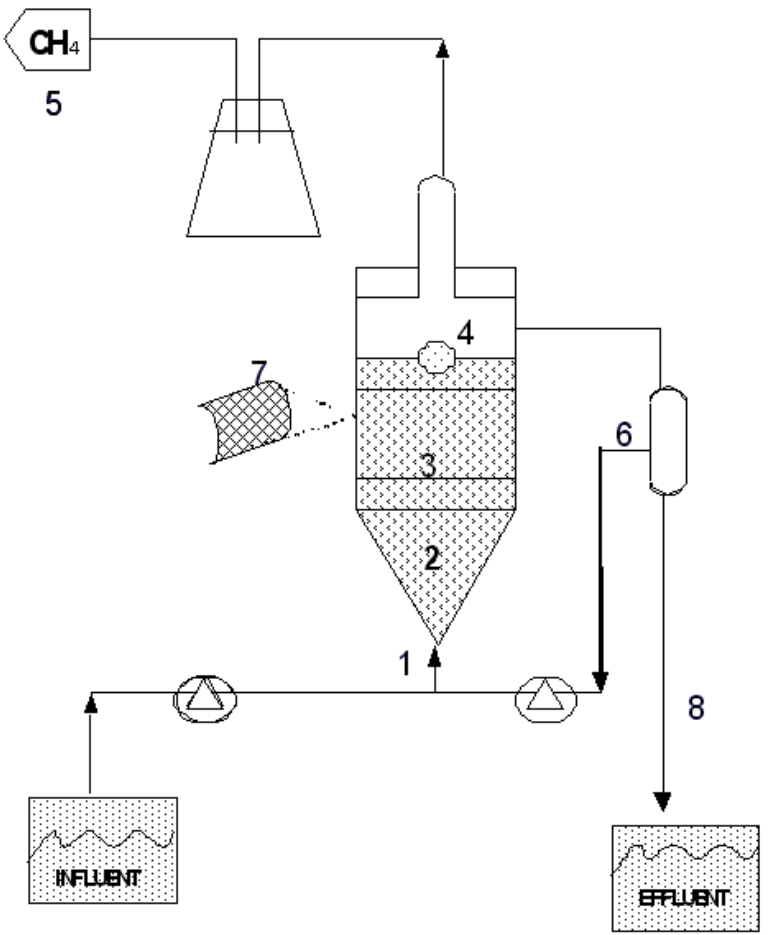

Figure 1. Diagram of the experimental AF reactor. 1: influent; 2: distributor; 3: sludge bed; 4: separation S/L/G; 5: biogas; 6 : recirculation; 7: support; 8 . effluent.

\section{MATERIALS AND METHODS}

\section{Influent}

The TCF synthetic influent was prepared to according to the principal concentrations present in common effluent. The basal medium was HCOONa $(500 \mathrm{mg} / \mathrm{L}), \mathrm{CH}_{3} \mathrm{COONa}$ $(100 \mathrm{mg} / \mathrm{L}), \mathrm{NaHCO}_{3}(4 \mathrm{~g} / \mathrm{L})$, DTPA and $\mathrm{Fe}$ (III). The chelating agent concentration was $107 \mathrm{mg} / \mathrm{L}$ and Fe (III) was added to ensure the formation Fe-chelate complex (Rodriguez et al. 1999).

The nutrient solution was prepared considering the follow mineral elements: $\mathrm{H}_{3} \mathrm{PO}_{4}(0.0032 \mathrm{mg} / \mathrm{L}), \mathrm{MgSO}_{4} \cdot 7 \mathrm{H}_{2} \mathrm{O}$ $(0.54 \mathrm{~g} / \mathrm{L}), \mathrm{CaCl}_{2} \cdot 2 \mathrm{H}_{2} \mathrm{O}(0.54 \mathrm{~g} / \mathrm{L}), \mathrm{FeCl}_{3} \cdot 6 \mathrm{H}_{2} \mathrm{O}(1.05 \mathrm{~g} / \mathrm{L})$, $\mathrm{NH}_{4} \mathrm{Cl}(2.085 \mathrm{~g} / \mathrm{L}), \mathrm{C}_{2} \mathrm{H}_{2} \mathrm{O}_{2}\left(50 \%\right.$ in $\left.\mathrm{H}_{2} \mathrm{O}\right)(3 \mathrm{mg} / \mathrm{L})$, $\mathrm{C}_{8} \mathrm{H}_{8} \mathrm{O}_{3}(0.8 \mathrm{~g} / \mathrm{L})$.

The influent fed to the AF consisted of $1 \mathrm{~L}$ of basal medium and $10 \mathrm{ml}$ of nutrient solution. Table 1 presents the synthetic influent's physicochemical characteristics. DPTA's COD value is $1.5 \mathrm{~g}$ COD/gDPTA.

\section{Anaerobic filter}

An AF (240 ml) was continuously operated for 200 days (Figure 1). The AF was supported by corrugated PVC 1.5$\mathrm{cm}$ diameter Raschig rings with a specific surface of 449 $\mathrm{m}^{2} / \mathrm{m}^{3}$. The reactor was spiked with $5 \mathrm{gVSS} / \mathrm{L}$ of anaerobic flocculent sludge, and placed in a thermostatic chamber at a 
constant temperature of $37^{\circ} \mathrm{C}$. The sludge's maximum specific methanogenic activity was $0.9 \mathrm{gCOD} / \mathrm{gVSS} \cdot \mathrm{d}$. The reactor was initiated with wastewater at a low DPTA Load Rate $\left(\mathrm{LR}_{\mathrm{DPTA}}\right)$, which increased progressively from 0.07 to $0.28 \mathrm{~g} \mathrm{DPTA} / \mathrm{L} \cdot \mathrm{d}$, and the Organic Load Rate (OLR) was increased from 0.17 to $1.4 \mathrm{gCOD} / \mathrm{L} \cdot \mathrm{d}$. The flow rate, $\mathrm{pH}$, COD, $\mathrm{BOD}_{5}$, DPTA, Total Alkalinity (TA) and alkalinity ratio were measured throughout the operation. An attached biomass characterization was also performed with a scanning microscope, following Belmar et al. (2004). Three different samples were collected from the AF's supporting material.

\section{Analytical methods}

Volatile Suspended Solid (VSS), Total Suspended Solid (TSS), Total Solid (TS), Volatile Solid (VS), Chemical Oxygen Demand (COD), and Biological Oxygen Demand $\left(\mathrm{BOD}_{5}\right)$ were measured using Standard Methods (APHA, 1985). DPTA was measured following Bhattacharya and Kundu (1971), adapting the methodology to EDTA. The maximum absorption of iron (III) and DPTA complex in $0.1 \mathrm{~N} \mathrm{H}_{2} \mathrm{SO}_{4}$ medium is at 305 and $258 \mathrm{~nm}$, respectively. Thus, DPTA can be calculated by adding the excess of $\mathrm{Fe}$ (III) to the absorbance measurements at the two wavelengths (Bhattacharya and Kundu, 1971). A calibrated curve of DPTA concentration vs. absorbance with statistic correlation $\left(\mathrm{r}^{2}\right)$ of 0.9999 was graphed (range of DPTA calibration: 25 to $125 \mathrm{mg} / \mathrm{L}$ ).

Samples for the COD, $\mathrm{BOD}_{5}$ and DPTA characterization were membrane filtered $(0.45 \mathrm{~mm})$. TA and the alkalinity due to VFA (Intermediate Alkalinity, IA) were determined by titration (Ripley et al. 1986). The IA/TA ratio is a very useful parameter because it checks correct digester operation, where a ratio below $0.3-0.4$ indicates that no VFA accumulation occurs (Fernandez et al. 1995).

Calculation of the sludge's maximum specific methanogenic activity was carried out in $100 \mathrm{~mL}$ serum bottles following the procedure previously described by Soto et al. (1993). A neutralized VFA stock solution was used to provide a final concentration of acetic acid (Hac) of $2 \mathrm{~g} / \mathrm{L}$, propionic acids (HPr) of $0.5 \mathrm{~g} / \mathrm{L}$, and n-butyric acid $(\mathrm{HnBu})$ of $0.5 \mathrm{~g} / \mathrm{L}$. The sludge concentration in the assays was $2.0 \mathrm{VSS} / \mathrm{L}$. To obtain a reducing medium, $100 \mathrm{mg}$ $\mathrm{Na}_{2} \mathrm{~S} \cdot 9 \mathrm{H}_{2} \mathrm{O} / \mathrm{L}$ were added. Diluted $\mathrm{HCl}$ or $\mathrm{NaOH}$ solutions were used to adjust the initial pH $7.0 \pm 0.1$. Nitrogen gas was bubbled up into each flask to remove air from the headspace. All assays were performed at $35^{\circ} \mathrm{C}$ (Soto et al. 1993).

Attached biomass characterization was made using scanning microscopy, according to Belmar et al. (2004). Three different samples (support area $1 \times 1 \mathrm{~cm}^{2}$ ) were collected from AF supporting material at the initial and final time of AF reactor operation. They were re-suspended with ultrasonic bath (power output of $90 \mathrm{~W}$ ) for $20 \mathrm{~min}$ at $4^{\circ} \mathrm{C}$ in a modified protoplasting buffer ( $0.45 \mathrm{M}$ sucrose). Then, they were washed in PBS buffer $(120 \mathrm{mM} \mathrm{NaCl}$ and $2.7 \mathrm{mM} \mathrm{KCl}$ in $10 \mathrm{mM} \mathrm{pH} 7.6$ phosphate buffer), and were evaluated using a scanning electronic microscope at magnifications 2.500x, 5.000x and 1.000x (Belmar et al. 2004)

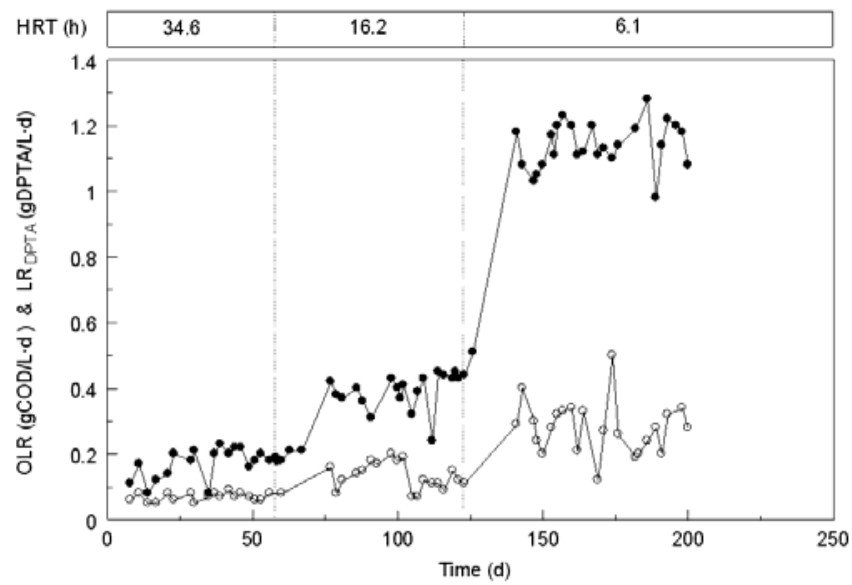

Figure 2. Reactor control parameters, $\operatorname{OLR}(\bullet)$ and $\operatorname{LR}_{\mathrm{DPTA}}(0)$.

\section{RESULTS AND DISCUSSION}

The biodegradation feasibility of Fe-DPTA-containing TCF bleaching effluent was studied using an AF reactor. To prevent methanogenic inhibition during reactor start-up and to promote gradual biomass acclimatization, the OLR was gradually increased from 0.17 to $1.4 \mathrm{gCOD} / \mathrm{L} \mathrm{x} \mathrm{d}$, whereas the Fe-DPTA organic load increased from 0.07 to 0.28 gDTPA/L x d and HRT from 34.6 to $6.1 \mathrm{hr}$ after 200 days (Figure 2).

The hydraulic conditions were kept complete stable for the second and third operating period with HRT 16.2 and 6.1

Table 2. Reactor performance during operation.

\begin{tabular}{|c|c|c|c|c|c|c|c|c|c|}
\hline \multirow[t]{2}{*}{ Period (d) } & \multirow{2}{*}{$\begin{array}{c}\text { OLR } \\
\text { (gCOD/L·d) }\end{array}$} & \multirow{2}{*}{$\begin{array}{l}\text { HRT } \\
\text { (h) }\end{array}$} & \multirow{2}{*}{$\begin{array}{c}\text { LR } \text { LRTPA } \\
\text { (gDTPA/L·d) }\end{array}$} & \multirow[t]{2}{*}{ pH effluent } & \multirow{2}{*}{$\begin{array}{c}\text { Total alkalinity } \\
\left(\mathrm{mgCaCO}_{3}\right)\end{array}$} & \multirow[t]{2}{*}{ Alkalinity ratio } & \multicolumn{3}{|c|}{ Removal } \\
\hline & & & & & & & $\operatorname{COD}(\%)$ & $\mathrm{BOD}_{5}(\%)$ & DTPA (\%) \\
\hline $1-64$ & $\begin{array}{c}0.17 \\
0.23-0.08\end{array}$ & $\begin{array}{c}34.6 \\
43.1-25.4\end{array}$ & $\begin{array}{c}0.07 \\
0.09-0.05\end{array}$ & $\begin{array}{c}8.7 \\
9.0-8.2\end{array}$ & $\begin{array}{c}2000 \\
2025-1550\end{array}$ & $\begin{array}{c}0.19 \\
0.22-0.18\end{array}$ & \begin{tabular}{|c|}
52.6 \\
$63.1-15.2$
\end{tabular} & $\begin{array}{c}95.0 \\
97.9-90.1\end{array}$ & \begin{tabular}{|c|}
5.28 \\
$19.8--14.5$
\end{tabular} \\
\hline $65-116$ & $\begin{array}{c}0.44 \\
0.43-0.24\end{array}$ & $\begin{array}{c}16.2 \\
21.3-14.5\end{array}$ & $\begin{array}{c}0.13 \\
0.18-0.07\end{array}$ & $\begin{array}{c}8.5 \\
8.9-8.1\end{array}$ & $\begin{array}{c}1954 \\
1900-1954\end{array}$ & $\begin{array}{c}0.13 \\
0.14-0.08\end{array}$ & $\begin{array}{c}52.4 \\
77.2-47.6\end{array}$ & $\begin{array}{c}94.4 \\
97.6-90.4\end{array}$ & $\begin{array}{c}0.05 \\
30.4-49.8\end{array}$ \\
\hline $117-200$ & $\begin{array}{c}1.4 \\
1.23-0.98\end{array}$ & $\begin{array}{c}6.2 \\
6.9-5.5\end{array}$ & $\begin{array}{c}0.28 \\
0.50-0.12\end{array}$ & $\begin{array}{c}8.1 \\
8.6-7.6\end{array}$ & $\begin{array}{c}1825 \\
2050-1625\end{array}$ & $\begin{array}{c}0.24 \\
0.30-0.16\end{array}$ & $\begin{array}{c}59.0 \\
67.6-51.2\end{array}$ & $\begin{array}{c}94.7 \\
98.1-94.7\end{array}$ & \begin{tabular}{|c|}
-26.16 \\
$9.4-68.0$
\end{tabular} \\
\hline
\end{tabular}


hrs, respectively (Figure 3a and Table 2). Figure 3b shows the alkalinity ratio and the $\mathrm{pH}$ throughout the operation. Total system alkalinity was around 2 gCaCO3/L (1.8 - 2.0 $\mathrm{gCaCO} / \mathrm{L}$ ) and the alkalinity ratio was always below 0.3 , indicating that no volatile fatty acid accumulation occurred (Ripley et al. 1986).

AF reactor efficiency can be observed in Figure 4 and Table 2. During operation, the maximum BOD5 removal was above $95 \%$, whereas COD was below to $59 \%$. As shown in Figure 4a, BOD5 removal remained stable during the entire operation. However, COD efficiency gradually increased from $40 \%$ to $59 \%$ as the anaerobic bacteria adapted. Figure $4 \mathrm{~b}$ and Figure $4 \mathrm{c}$ show DPTA was accumulated in the reactor due to DPTA adsorption/desorption on the biomass. The increases in DPTA concentration in the effluent are due to the AF feeding strategy (Figure 2).
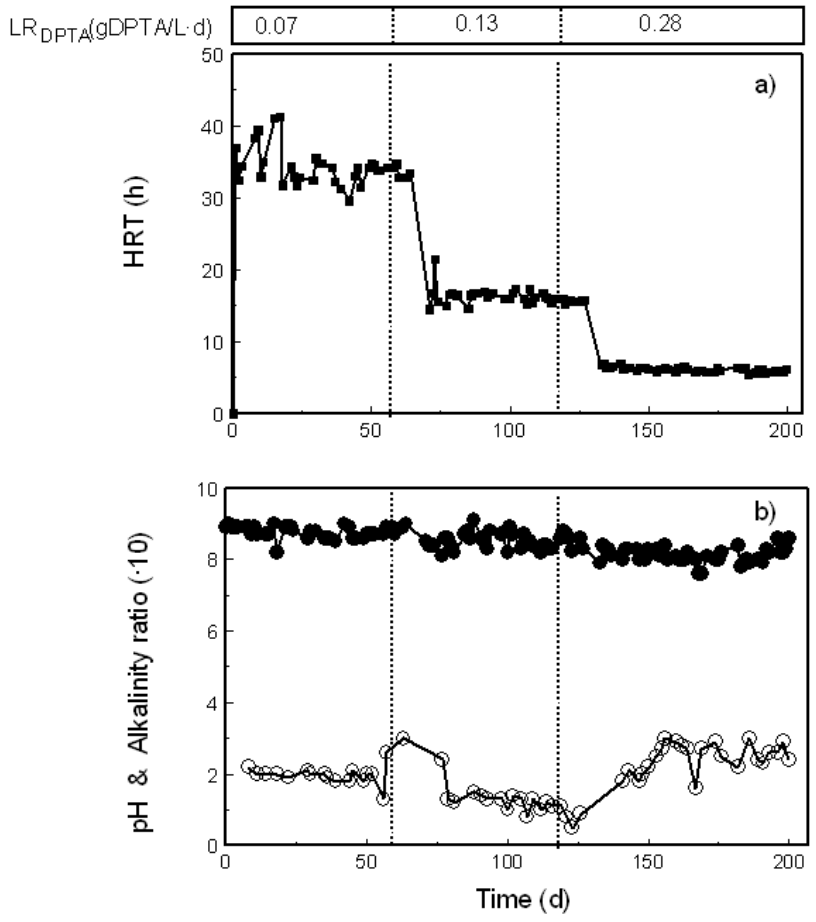

Figure 3. AF reactor performance.

(a) $\operatorname{HRT}(\boldsymbol{\square})$.

(b) $\mathrm{pH}(\bullet)$ and Alkalinity ratio (o).

Considering the AF's BOD5 removal efficiency, it can be concluded that methanogenic activity was conserved, even with presence of Fe-DPTA in the reactor. Indeed, electronic microscope biofilm studies (Figure 5a) show the inoculum constitution at time zero (magnification 2.500x) with a diversity of anaerobic bacteria in the biomass. In contrast, the biofilm studies (magnification 2.500x) at the end of AF operation (Figure 5b) indicate anaerobic microorganism selection (rod and coccus morphology). Due to this selection, biomass concentration inside the reactor decreased from 1.2 gVSS (start-up of AF reactor) to 1.0 gVSS (final concentration of AF operation). Belmar et al.
(2004) show that in the support biofilms of a Fe-EDTAtreating AF reactor, $34.6 \%$ of the bacteria are archeas and the methanosarcinas sp. is most important population (35\%). Result extrapolation to Fe-DPTA indicates that methanogenic bacteria will continue operating in presence of Fe-DPTA compounds.

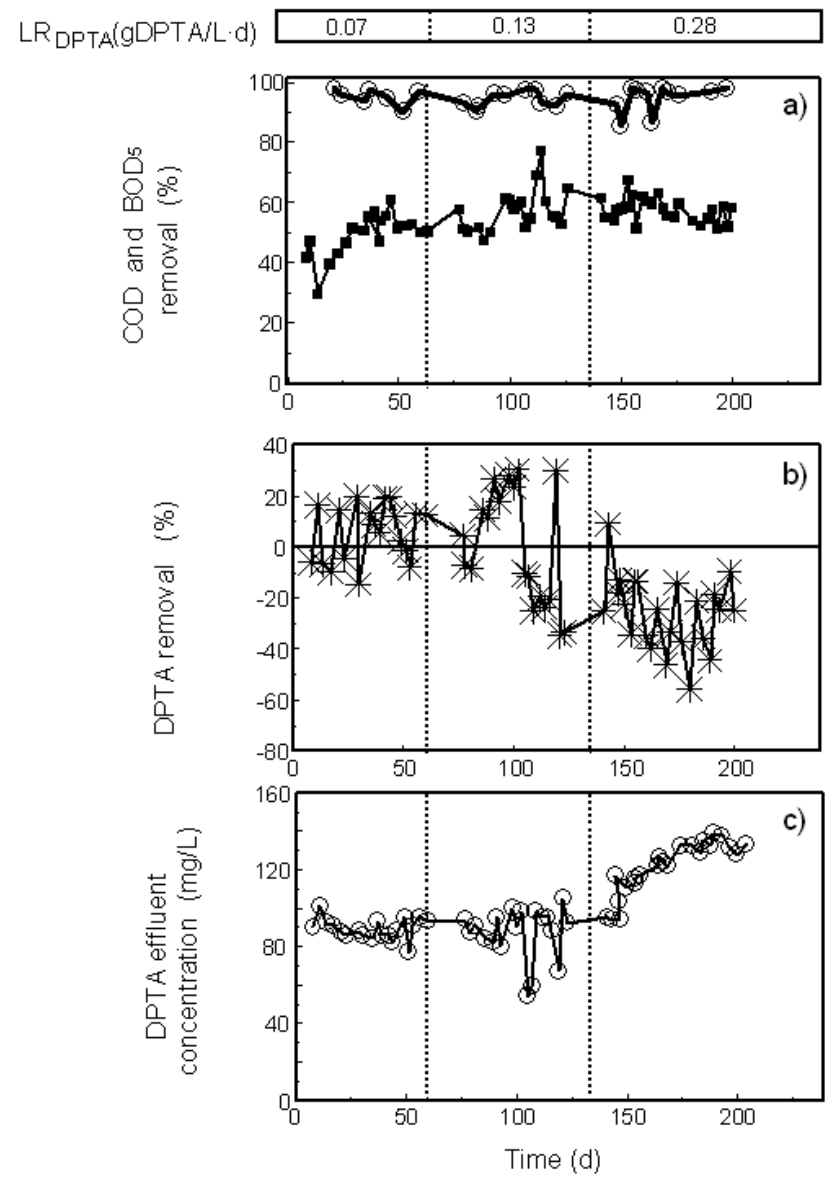

Figure 4. Removal of:

(a) $\operatorname{COD}(\mathbf{\square})$ and $\mathrm{BOD}_{5}(0)$.

(b) DPTA (*).

(c) Concentration of the effluent DPTA (o).

However, during the first operating period (1 - 64 days), only $5 \%$ of Fe-DPTA was removed, and this was probably due to adsorption. The recalcitrant COD fraction can be explained by the non-mineralized DPTA fraction under anaerobic conditions because EDTA and DPTA biodegradability depends on metal complex stability. If Ca and $\mathrm{Mg}$ ions exist in stoichiometric excess, the composition of the metal complexes will slowly be displaced in favour of the more degradable $\mathrm{Ca}$ and $\mathrm{Mg}$ complexes (Henneken et al. 1996). However, other evidence indicates that pure Fe-EDTA and Fe-DPTA complex is biodegradable under aerobic conditions (Lauff et al. 1990), although there is no evidence on the anaerobic biodegradation of these kraft mill effluent compounds. The evolution of Fe-DPTA removal (Figure $4 \mathrm{~b}$ ) shows that the Fe-DPTA removal efficiency 
during the first 116 days of AF operation is due to adsorption/desorption phenomena. Moreover, Figure 4b shows that after 116 days of operation, the AF reactor increases the effluent's DPTA-Fe concentration. This phenomenon is probably due to saturation of biomass adsorption capacity. Moraga et al. (2002) reported preliminary adsorption/desorption results, indicating that when biological materials and activated carbon adsorb chelates, adsorption phenomena can be described by a Freundlich-type isotherm. They reported that the best adsorption conditions are at low $\mathrm{pH}(>5.0)$ and low temperature $\left(20^{\circ} \mathrm{C}\right)$; while when $\mathrm{pH}>7.0$ and temperature $>50^{\circ} \mathrm{C}$, desorption can take place.

Results from this study suggest that Fe-DPTA shows recalcitrant behaviour to be degraded by anaerobic bacteria (Figure 4b). Prior to the mentioned study, only aerobic biodegradation of chelate compounds had been found (Kaluza et al. 1998; Diez et al. 2005). However, combined technologies, including advanced oxidation processes and biological treatment (Rodriguez et al. 1999), may remove Fe-DPTA compounds. Moreover, Virtapohja and Alen (1999) found that the DPTA's photochemical conversion is faster than that of EDTA. Theoretical half-lives of 8.0 and 11.3 min were found for the DPTA and EDTA iron (III) complexes, respectively.

\section{CONCLUDING REMARKS}

Continuous TCF effluent biodegradation at different organic load rates $(0.17$ - $1.4 \mathrm{~g} \mathrm{COD} / \mathrm{L} \times \mathrm{d})$ indicates incomplete COD biodegradation (up to 59\%) due to DPTA's recalcitrant behaviour. Still, $\mathrm{BOD}_{5}$ biodegradation

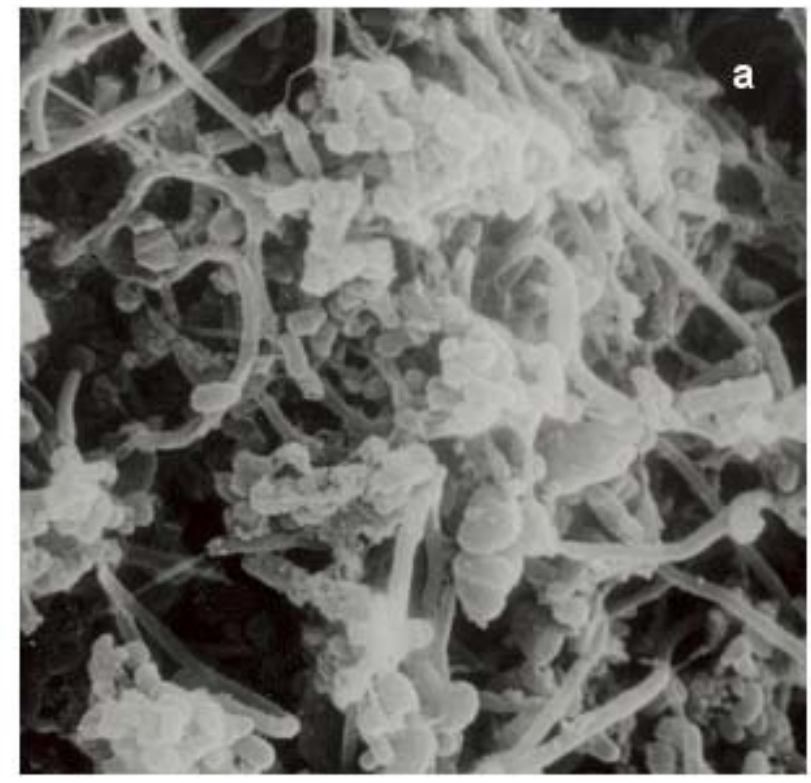

was above 95\%. Electronic microscopic biofilm studies show that the synthetic influent selected anaerobic microorganisms (rod and coccus morphology).

The recalcitrant biodegradation of Fe-DPTA is related with complex stabilization and also with chemical stoichiometry. Advanced treatment could be the best process to degrade this compound.

\section{REFERENCES}

ALDER, Alfredo C.; SIEGRIST, Hansruedi, GUJER, Willi and GIGER, Walter. Behaviour of NTA and EDTA in biological wastewater treatment. Water Research, June 1990, vol. 24, no. 6, p. 733-742.

American Public Health Association, American Water Works Association, Water Pollution Control Facilities (APHA-AWWA-WPCF). Standard Methods for Examination of Water and Wastewater. 16th ed. Washington.1985, 1085 p. ISBN 0-87553-235-7.

BELMAR, A.; DECAP, J.; SOSSA, K.; URRUTIA H. and VIDAL. G. Methanogenic population dynamics during anaerobic biodegradation of TCF effluent by a system with attached biomass. In: World Congress of Anaerobic Digestion - Anaerobic bioconversion an answer for sustainability. (10th, 29th August- 2nd September, 2004, Montreal, Canada), Proceedings, 2004,vol. 3, p.1603-1605.

BHATTACHARYA, S.N. and KUNDU, K.P. Spectrophotometric determination of EDTA. Talanta, 1971, vol. 18, no. 4, p. 446-448.

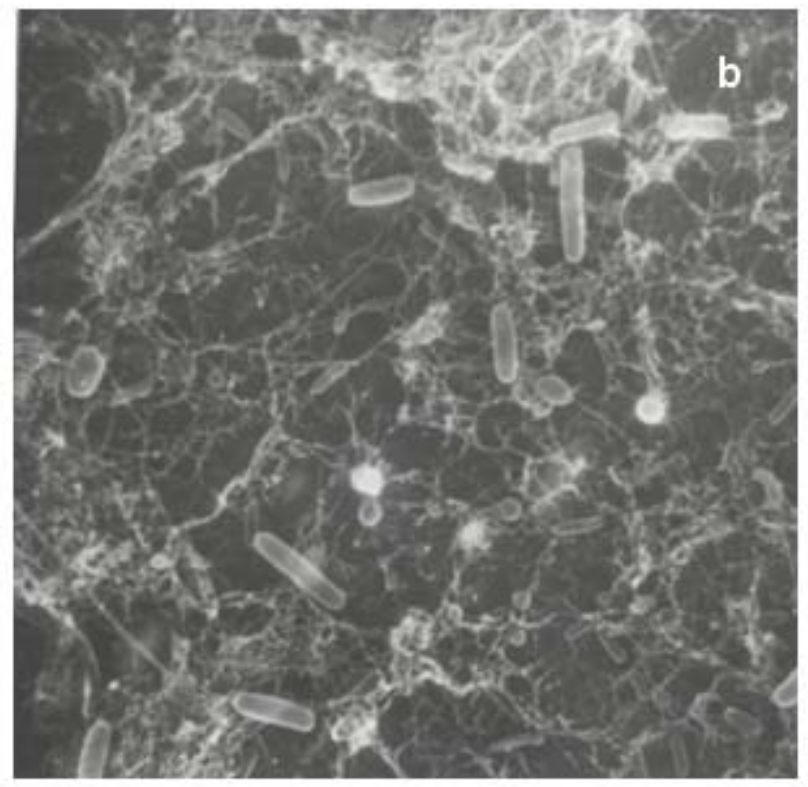

Figure 5. Microorganism attached to rashing support.

(a) Initial inoculum (2.500x).

(b) Microorganisms selection at final time of the AF operation (2.500x). 
DIEZ, M.C.; POLEURS, D.; NAVIA, R. and VIDAL, G. Effect of EDTA and Fe-EDTA complex concentration on TCF kraft mill effluent degradation. Water Research, 2005, vol. 39, no. 14, p. 3239-3246.

FERNANDEZ, J.; MENDEZ, R. and LEMA, J.M. Anaerobic treatment of eucalyptus fiberboard manufacturing wastewater by hybrid USBF lab-scale reactor. Environmental Technology, 1995, vol. 16, no. 7, p. 677-684.

HENNEKEN, L.; NÖRTEMANN, B. and HEMPEL, D.C. Influence of physiological conditions of EDTA degradation. Applied Microbiology and Biotechnology, 1996, vol. 44, no. 1-2, p.190-197.

HINCK, M.L.; FERGUSON, J. and PUHAAKKA, J. Resistance of EDTA and DTPA to aerobic biodegradation. Water Science and Technology, 1997, vol. 35, no. 2-3, p. 25-31.

KALUZA, U.; KLIGELHOFER, P. and TAEGER, K. Microbial degradation of EDTA in an Industrial wastewater treatment plant. Water Research, 1998, vol. 32, no. 9, p. 2343-2845.

LAUFF, J.J.; STEELE, D.B.; COOGAN, L.A. and BREITFELLER, J.M. Degradation of the ferric chelate of EDTA by a pure culture of an Agrobacterium sp. Applied and Environmental Microbiology, November 1990, vol. 56, no. 11, p. 3346-3353.

LARISCH, B.C. and DUFF, S.J.B. Effect of DPTA and EDTA on activated sludge reactors treating bleached kraft mill effluent. Tappi Journal, 2000, vol. 83, no. 6, p. 54-60.

MORAGA, C.H.; DOMINGUEZ, V. and VIDAL, G. EDTA adsorption arising new kraft mill bleaching effluents. In: Proceedings 3eras Jornadas Chilenas de Física y Química Ambiental (4-6 December 2002, Santiago, Chile). 2002, vol. 1, p. 36.

RIPLEY, L.E.; BOYLE, J.C. and CONVERSE, J.C. Improved alkalimetric monotoring for anaerobic digestion of high strength wastes. Journal of the Water Pollution Control Federation, 1986, vol. 58, no. 5, p. 406-411.

RODRIGUEZ, J.; MUTIS, A.; YEBER, M.C.; FREER, J.; BAEZA, J. and MANSILLA, H.D. Chemical degradation of EDTA and DTPA in totally chlorine free (TCF) effluent. Water Science and Technology, 1999, vol. 40, no. 11-12, p. 267-272.

SAUNAMÄKI, R. Treatability of wastewaters from totally chlorine free bleaching. Tappi Journal, 1995, vol. 78, no. 8, p. $185-192$.

SOTO, M.; MÉNDEZ, R. and LEMA, J.M. Methanogenic and non-methanogenic activity test. Theoretical basis and experimental set-up. Water Research, 1993, vol. 27, no. 8, p. 1361-1367.

SUSS, H.U. and NIMMERFROH, N.F. Peroxide bleaching technology review. In: Proceedings North Caroline State Emerging Technologies Seminar (8-10 March 1993, Raleigh, USA). 1993, p. 167-173.

VAN GINKEL, G.; VIRTAPOHJA, J.; STEYAERT, J.A. and ALEN, R.J. Treatment of EDTA containing in pulp and paper mill wastewaters in activated sludge plants. Tappi Journal, 1999, vol. 82, no. 2, p. 138-142.

VAN GINKEL， G.; VANDENBROUCKE， K.L. and STROO, C.A. Biological removal of EDTA in conventional activated sludge plants operated under alkaline conditions. Bioresource Technology, 1997, vol. 59, no. 2-3, p. 151-155.

VIDELA, S. and DIEZ, M.C. Experiences of wastewater treatment in chilean forest industry. Water Science and Technology, 1997, vol. 35, no. 2-3, p. 221-226.

VIRTAPOHJA, J. and ALEN, R. Fate of EDTA and DPTA in the pulp and paper industries. In: International symposium on wood and pulping chemistry. (10th, 7th 10th June, 1999, Yokohama, Japan). Biennale ISWPC, 1999, vol. 1, p. 280-285. 